\title{
EHMTI-0234. Glyceryl trinitrate provoked mast cell degranulation is secondary to the release of nitric oxide in vivo
}

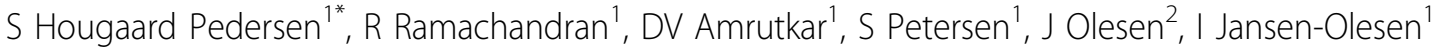 \\ From 4th European Headache and Migraine Trust International Congress: EHMTIC 2014 \\ Copenhagen, Denmark. 18-21 September 2014
}

\section{Introduction}

Infusion of the nitric oxide (NO) donor, glyceryl trinitrate (GTN), provokes a migraine-like attack in migraineurs and cFos up-regulation in rat trigeminal nucleus caudalis. We studied the level of dura mast cell degranulation after infusion of GTN in awake, freely moving rats and hypothesized that the degranulation is secondary to NO.

\section{Aims}

We studied the effect on dura mast cell degranulation of NO from GTN in vivo and of GTN and sodium nitroprusside (SNP) ex vivo.

\section{Methods}

GTN was infused i.v. in rats and mast cell degranulation was evaluated at different time points (Approved by Animal Experiments Inspectorate). Dura mater was subjected to GTN and SNP ex vivo and mast cell degranulation was likewise evaluated. Release of NO was confirmed by cerebral artery relaxation in a wire myograph setup.

\section{Results}

GTN infusion in vivo induced a significant mast cell degranulation in a time-dependent manner. Degranulation increased from $30 \mathrm{~min}(20.3 \pm 3.0 \%)$ to 2 hours $(61.0$ $\pm 15.3 \%)$ reaching a stable level for at least 6 hours (54.5 $\pm 9.3 \%)$. In an ex vivo setup, neither of the NO donors GTN $(9.65 \pm 1.17 \%)$ or SNP $(11.63 \pm 3.46 \%)$ caused mast cell degranulation compared to vehicle $(11.65 \pm 2.89 \%$ and $9.97 \pm 3.09 \%$, respectively) after $10 \mathrm{~min}$. Cerebral arteries

${ }^{1}$ Glostrup Research Institute, Danish Headache Center, Glostrup, Denmark Full list of author information is available at the end of the article dilated significantly in response to both GTN $(68.0 \pm 1.0 \%)$ and SNP $(73.5 \pm 2.5 \%)$.

\section{Conclusions}

In vivo infusion of GTN caused significant mast cell degranulation $30 \mathrm{~min}$ to at least $6 \mathrm{hrs}$ after infusion, suggesting a secondary effect of NO. In support of this, direct application of NO did not degranulate dura mast cells ex vivo.

No conflict of interest.

Authors' details

${ }^{1}$ Glostrup Research Institute, Danish Headache Center, Glostrup, Denmark

²Department of Neurology, Danish Headache Center, Glostrup, Denmark.

Published: 18 September 2014

doi:10.1186/1129-2377-15-S1-F10

Cite this article as: Pedersen et al.: EHMTI-0234. Glyceryl trinitrate provoked mast cell degranulation is secondary to the release of nitric oxide in vivo. The Journal of Headache and Pain 2014 15(Suppl 1):F10.

Submit your manuscript to a SpringerOpen ${ }^{\bullet}$ journal and benefit from:

- Convenient online submission

- Rigorous peer review

- Immediate publication on acceptance

- Open access: articles freely available online

- High visibility within the field

- Retaining the copyright to your article

Submit your next manuscript at $>$ springeropen.com (c) 2014 Pedersen et al; licensee Springer. This is an Open Access article distributed under the terms of the Creative Commons Attribution License (http://creativecommons.org/licenses/by/2.0), which permits unrestricted use, distribution, and reproduction in any medium, provided the original work is properly cited. 